\title{
ALTERNATIF PENGEMBANGAN RUANG PUBLIK KOTA: TAMAN SPOT BUDAYA DUKUH ATAS - JAKARTA
}

\author{
Gerry $^{1}$, Erwin Fahmi ${ }^{2}$ \\ ${ }^{1}$ Program Studi Magister Perencanaan Wilayah dan Kota, Universitas Tarumanagara \\ Email: gerryatmadja@gmail.com \\ ${ }^{2}$ Program Studi Magister Perencanaan Wilayah dan Kota, Universitas Tarumanagara \\ Email: erwin.fahmi@gmail.com
}

Masuk: 20-02-2021, revisi: 30-09-2021, diterima untuk diterbitkan: 06-10-2021

\begin{abstract}
ABSTRAK
Sejak akhir 1980-an bisnis properti berkembang pesat di Indonesia, khususnya di Jakarta. Perkembangan ini mengkonversi lahan-lahan terbuka hijau menjadi lahan dengan fungsi komersil. Seiring perkembangan tersebut, terjadi pula pergeseran sosial di Jakarta dan di kotakota penyangganya. Masyarakat memaksimalkan perolehannya dari bekerja di kantor atau berdagang demi menjaga (dan meningkatkan) kesejahteraannya. Akibatnya, waktu luang untuk rekreasi (termasuk menikmati taman) menjadi berkurang. Taman Spot Budaya Dukuh Atas (TDA) adalah salah satu solusi Pemda DKI Jakarta dalam memberikan fasilitas ruang terbuka, sekaligus melayani kategori warga kota tersebut. Peninjauan apresiasi pengguna, adaptasi dengan kecenderungan yang ada, dan kesesuaiannya sebagai ruang publik serta ruang ketiga menjadi tolok ukur bagi alternatif pengembangan ruang publik modern. Penelitian ini menggunakan pendekatan penelitian kualitatif, dengan metode studi kasus. TDA dapat menjadi pilihan masyarakat untuk menikmati ruang publik, khususnya di pusat kota. TDA sendiri sudah memenuhi kriteria sebagai ruang publik dan ruang ketiga, serta sudah sesuai dengan tujuan awal Pemda DKI. Namun diperlukan pemeliharaan dan pengembangan dari pengelola taman yang lebih baik, agar ruang publik dapat berkelanjutan. Konsep penyediaan ruang publik yang dapat dinikmati secara singkat ini diharapkan dapat direplikasi di beberapa titik keramaian di Jakarta dan kota besar lainnya ke depan.
\end{abstract}

Kata kunci: Dukuh Atas; ruang terbuka hijau; apresiasi pengguna; ruang publik modern.

\begin{abstract}
Since the end of the 1980s Indonesia's property business has been growing rapidly, especially in Jakarta. The growth has transformed green open space gradually to commercial uses. Along with that, there has also been a social shift in Jakarta and its satellite cities. Citizen maximizes their earnings from working at the office and trading in order to maintain (and upgrade) their welfare. As a result, their leisure time (including enjoying the park) worn off. Taman Spot Budaya Dukuh Atas (TDA) has been a Jakarta provincial government's solution to such issues, i.e decreasing number of parks and open spaces, and the limited time available to enjoy them. A review in user appreciation, adaptation to current and upcoming trends, and its compatibility as public space and third space will be a benchmark for modern public space development. This study applies a qualitative research approach with a case study method. TDA proves to be one of the people's option to hang out at public space, especially in a crowded city district. TDA also fulfilled public space, third space, and Jakarta government's goals. But better maintenance and improvement are needed to ensure its sustainability. The concept of public space that can be enjoyed in a short time are expected to be replicated to several other crowd points in Jakarta and other major cities in the future.
\end{abstract}

Keywords: Dukuh Atas; green open space; user appreciation; modern public space 


\section{PENDAHULUAN}

\section{Latar Belakang}

Sejak dekade 1980-an bisnis properti berkembang pesat di Indonesia, khususnya di Jakarta (Priatmodjo, 2012: 5). Sejalan dengan pengembangan tersebut, sejumlah lahan RTH (Ruang Terbuka Hijau) dikonversi menjadi lahan dengan fungsi komersial. Beberapa contohnya adalah (1) Taman Pluit yang dulunya merupakan taman kota seluas 20 hektar, kini menjadi Pluit Village; (2) Sisi utara dari bekas Bandara Kemayoran sebelumnya direncanakan menjadi taman kota, berubah menjadi lapangan golf; (3) Kompleks Olahraga Senayan yang diniatkan sebagai paru-paru kota sekarang dikelilingi oleh bangunan-bangunan besar, salah satunya lifestyle center di Taman Ria Senayan yang hadir pada tahun $2020^{1}$ dengan nama Senayan Park Mall.

RTH Jakarta mengecil dari 25,85\% (1985), 14.7\% (2000), dan 9.8\% (2013), namun pada tahun 2019 meningkat sedikit menjadi 9,98\%. Hal terakhir ini merefleksikan mulai menguatnya kebutuhan akan RTH di Jakarta. Selain berfungsi sebagai paru-paru kota, RTH dalam bentuk ruang publik juga menjadi sarana masyarakat bersosialisasi. Ruang publik yang dimaksud adalah public space yang berbentuk fisik, bukan public sphere (ranah publik) yang berbentuk nir-fisik seperti aplikasi media sosial (Jürgen Habermas dalam Terzi dan Tonnelat, 2016: 520).

Kerinduan akan ruang publik tercermin pada besarnya antusiasme masyarakat dalam mengikuti acara car-free day yang diselenggarakan oleh Pemda $\mathrm{DKI}^{2}$. Kebutuhan akan ruang terbuka publik juga terefleksikan dalam kehidupan sehari-hari warga kota. Masyarakat menciptakan ruang publik mereka sendiri, dengan memanfaatkan ruang yang ada sebagai lapangan bermain (Gambar 1 dan Gambar 2). Hal ini menjadi salah satu kritik terhadap kurangnya ruang publik di Jakarta (Priatmodjo, 2012: 7-9).

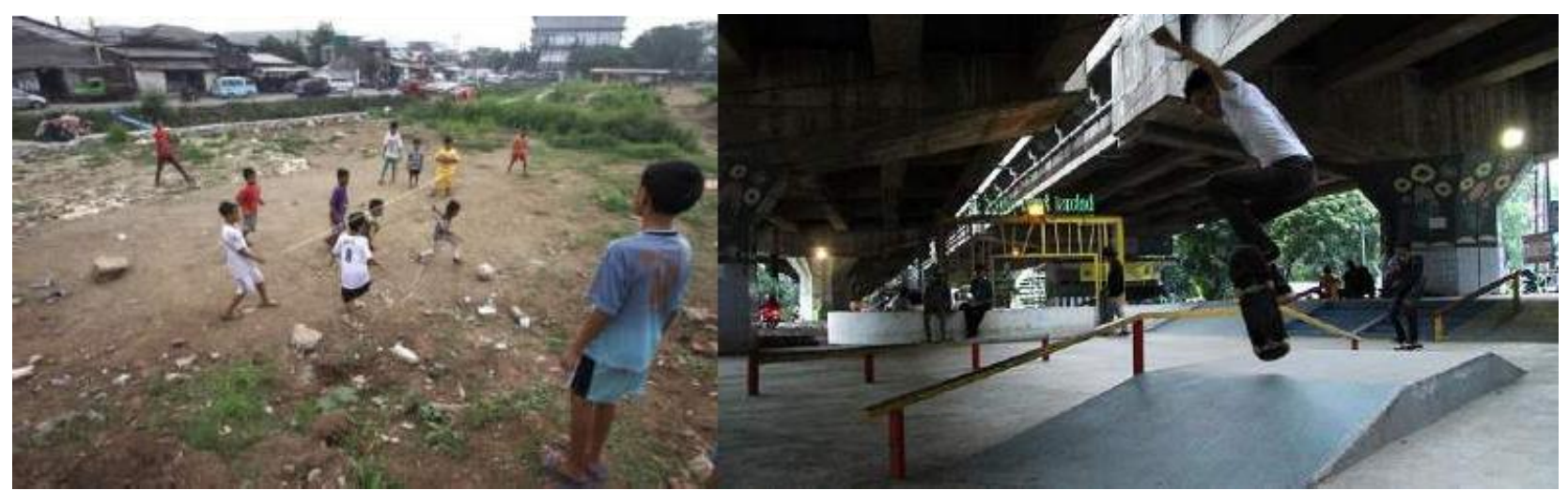

Gambar 1. Anak-anak Bermain di Lahan Kosong dan Skatepark di Bawah Fly Over Sumber: antarafoto.com dan tempo.co

\footnotetext{
${ }^{1}$ Hilda B. Alexander, "4 Mall Baru Bakal Hadir di Jakarta, Termasuk Taman Ria Senayan”, https://properti.kompas.com/read/2020/01/14/134444921/4-mall-baru-bakal-hadir-di-jakarta-termasuk-taman-riasenayan?page=all $($ diakses 10 Februari 2020)
} 
${ }^{2}$ Acara car free day atau hari bebas kendaraan bermotor (HBKB) telah mulai dilaksanakan secara tidak rutin sejak tahun 1990-an sebagai bagian dari kampanye tertentu, misalnya kampanye bensin bebas timbal. Namun, secara resmi kegiatan tersebut baru dimulai pada tahun 2002, dan dikokohkan dengan Instruksi Gubernur No 78/2011 tentang Pelaksanaan Hari Bebas Kendaraan Bermotor. Ingub ini sejalan dengan Peraturan Daerah No. 1/2005 tentang Pengendalian Pencemaran Udara.

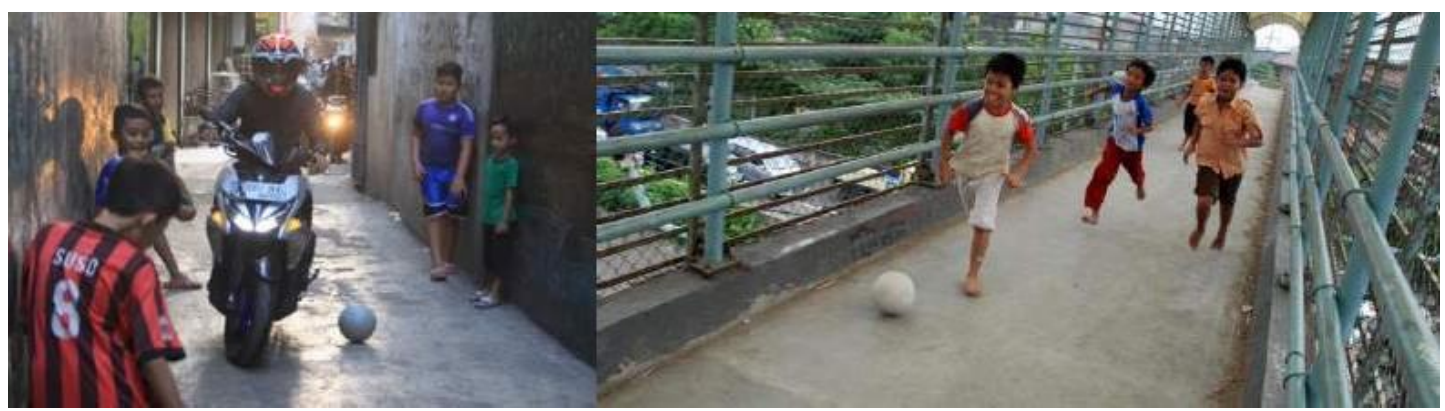

Gambar 2. Bermain di Tengah Jalan dan di Jembatan Penyeberangan di Jakarta Sumber: m.ayobandung.com dan republika.co.id

Paralel dengan upaya menambah luas RTH, Pemda DKI juga membangun apa yang disebut sebagai ruang ketiga (third space). Tujuan pembangunan ini, sebagaimana disampaikan oleh Gubernur DKI Jakarta pada peresmian Taman Spot Budaya Dukuh Atas (TDA, Agustus 2019) adalah sebagai tempat bertemu, berekspresi, dan berkegiatan, serta menikmati pengalaman berbeda setiap harinya ${ }^{3}$.

Konsep ruang ketiga antara lain dibahas oleh Oldenburg (1991: 6). Ia mendefinisikan ruang ketiga sebagai ruang sekitar yang terpisah dari dua ruang yang lebih dikenal, yaitu rumah (ruang pertama) dan tempat bekerja (ruang kedua). Soja (1996: 138) dalam studi kasusnya di kota Los Angeles mendefinisikan ruang ketiga sebagai ruang sosial, tempat aktivitas seharihari berlangsung. Ruang ini merupakan paduan ruang fisik dan ruang mental seperti yang dikemukakan oleh Lefebvre (1991: 9). Ruang ketiga adalah ruang yang tidak secara "resmi" direncanakan, tetapi secara nyata berlangsung aktivitasnya.

Lokasi TDA merupakan bekas jalan raya untuk kendaraan bermotor yang diubah menjadi ruang publik (lihat Gambar 3). Lokasi ini merupakan simpul 3 (tiga) moda transportasi utama Jakarta, yakni: bis (TransJakarta dan bis kota non-TransJakarta), KRL (Kereta Rel Listrik) dan kereta api bandara.

Dalam jarak yang tidak terlalu jauh, juga terdapat halte MRT (Moda Raya Terpadu-kereta subway). Dengan demikian, TDA merupakan simpul penting pergerakan warga dari rumah menuju tempat kerja di Jalan Sudirman atau Jalan Thamrin, dan sebaliknya. Simpul ini akan semakin padat aktivitas mengingat pergeseran sosial yang terjadi di kota-kota penyangga Jakarta, berupa semakin banyaknya persentase pekerja swasta (Ibrahim dalam Suryana, 2020: 10). Dengan jarak tempuh yang semakin jauh menuju tempat kerja, maka semakin sedikit pula waktu luang yang tersisa untuk menikmati ruang publik. TDA menawarkan alternatif tempat beristirahat dan menikmati ruang publik bagi kategori warga tersebut.

\footnotetext{
${ }^{3}$ Ibnu Haryanto, “Anies Baswedan Resmikan Taman Spot Budaya 2 di Dukuh Atas”, news.detik.com/berita/d4670525/anies-baswedan-resmikan-taman-spot-budaya-2-di-dukuh-atas (diakses pada 27 Januari 2020)
} 


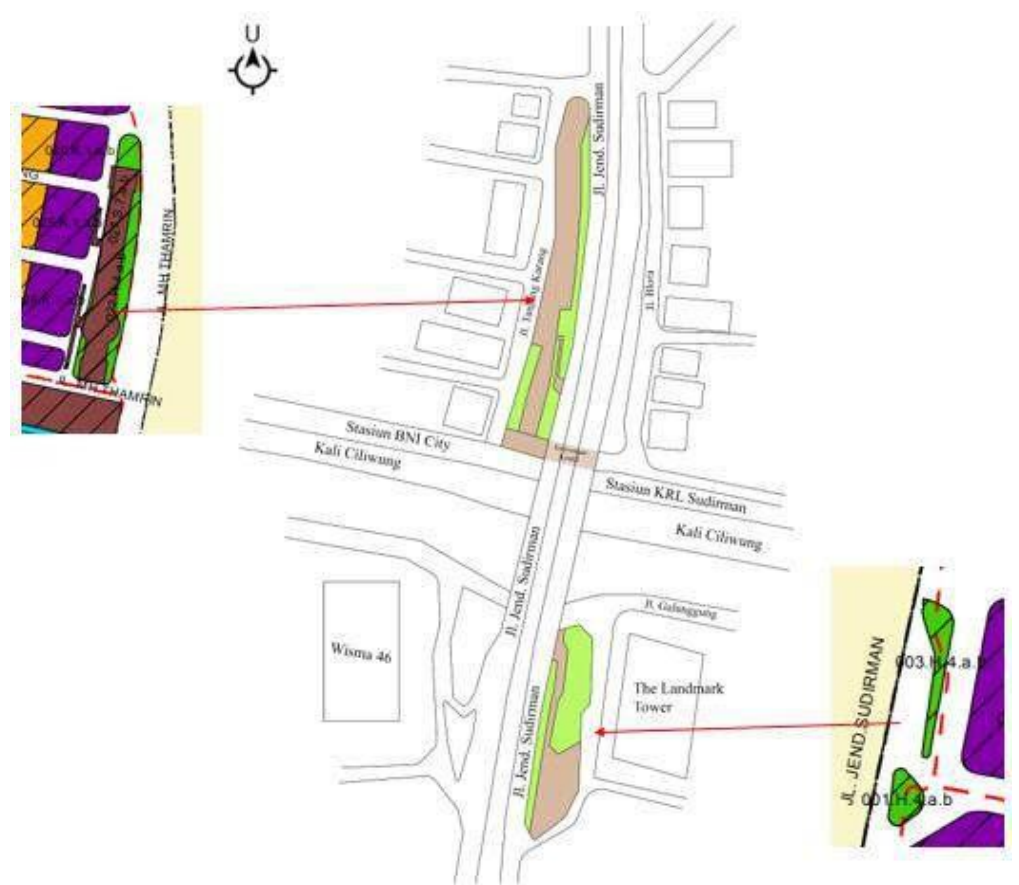

Gambar 3. Transformasi pada Kawasan Taman Dukuh Atas

Sumber: RTRW DKI Jakarta dan Olahan Penulis

\section{Rumusan Masalah}

Penelitian tentang alternatif pengembangan ruang publik kota di TDA ini dilakukan dalam upaya mengkaji arti penting TDA bagi kota Jakarta dan meninjau apresiasi warga kota terhadap model ruang publik baru tersebut. Selain itu, kajian juga akan menunjukkan hal-hal yang perlu terus ditingkatkan, berkaitan dengan pengelolaan dan pemeliharaan elemen ruang publik modern ${ }^{4}$, agar TDA semakin memenuhi tujuan keberadaannya.

\section{METODE PENELITIAN}

Studi ini dilaksanakan dengan pendekatan penelitian kualitatif. Penelitian (dengan pendekatan) kualitatif atau konstruktivis adalah penelitian yang menggunakan proses induktif, secara ontologis dipahami bahwa realitas bersifat subyektif dan ganda, serta secara aksiologis bersifat tidak bebas nilai (value-laden) (Creswell, 1994: 5). Proses pengumpulan data dalam penelitian ini terutama menggunakan wawancara tidak-terstruktur, observasi lapangan, pengamatan artefak, dan interpretasi data sekunder. Penelitian kualitatif ini juga menggunakan pendekatan studi kasus. Menurut Stakes (1994: 236) studi kasus lazimnya dipilih karena “... it draws attention to the questions what specifically can be

\footnotetext{
${ }^{4}$ Ruang publik modern di sini diartikan sebagai ruang publik yang cepat beradaptasi dengan kegiatan masyarakat di sekitarnya, dalam hal ini dapat dinikmati secara singkat tanpa harus singgah untuk waktu yang lama (Margono dan Zuraida, 2019: 27-31).

learned from the single case". Secara spesifik, studi kasus ini termasuk intrinsic case study, karena "...one wants better understanding of this particular case" (Stakes, 1994: 237). Studi kasus intrinsik dipilih bukan karena mewakili atau mengilustrasikan kasus-kasus lain, atau sifat tertentu, namun "... in all its particularity and ordinariness, this case itself is of interest" (Stakes 1994: 237).

Mengikuti Stakes (1994), kasus ini layak dikaji dengan pendekatan studi kasus intrinsik karena sejumlah keunikannya, yakni:
} 
a. Sifat kasus itu sendiri, yaitu penyediaan ruang publik yang relatif baru di Jakarta, dan dengan mengubah jalan raya;

b. Latar belakang kasus, yaitu tujuannya untuk menjadikan TDA sebagai ruang ketiga namun sifatnya terencana. Berbeda dengan ruang ketiga di Indonesia umumnya yang sifatnya tidak terencana;

c. Setting fisik kasus, yaitu berada di antara kawasan komersil di pusat kota Jakarta;

d. Karakteristik pengunjungnya yang heterogen. Menurut observasi, pengunjung TDA beragam, mulai dari berbagai komunitas seni, penggiat olah raga tertentu, hingga pekerja kantor.

Lokasi penelitian adalah TDA dengan luas $\pm 12.000 \mathrm{~m} 2$ dan terbagi menjadi 2 bagian, yaitu TDA 1 dan 2 (Gambar 4). TDA 1 berfungsi sebagai transit hub untuk transportasi umum; TDA 2 memfasilitasi kegiatan seperti skateboard dengan adanya skate park serta pagelaran musik dan budaya.

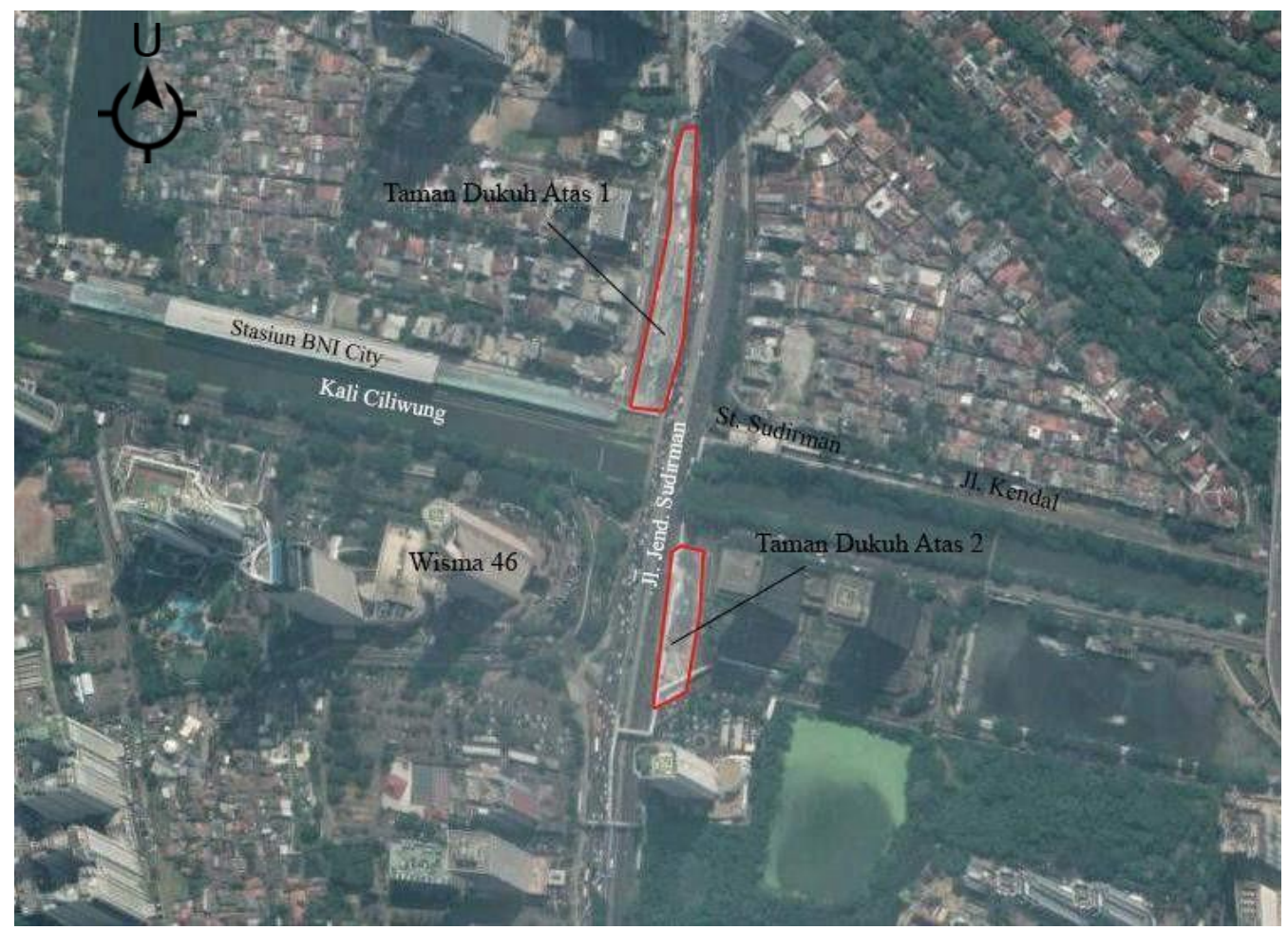

Gambar 4. Delineasi Lokasi Penelitian

Sumber: Google Earth (diakses Agustus 2020)

\section{HASIL DAN PEMBAHASAN}

\section{Aksesibilitas dan Konektivitas}

Untuk akses dari transportasi umum ke TDA 1, moda transportasi terdekat adalah MRT melalui Stasiun Dukuh Atas, metrotrans dari halte-halte bus di bahu jalan Jend. Sudirman, kereta bandara melalui Stasiun BNI City, dan KRL melalui Stasiun Sudirman. Sementara untuk TDA 2, moda transportasi terdekat adalah bus Transjakarta melalui halte Dukuh Atas 1, metrotrans dari haltehalte bus di bahu jalan Jend. Sudirman, dan KRL melalui Stasiun Sudirman (lihat Gambar 5). 


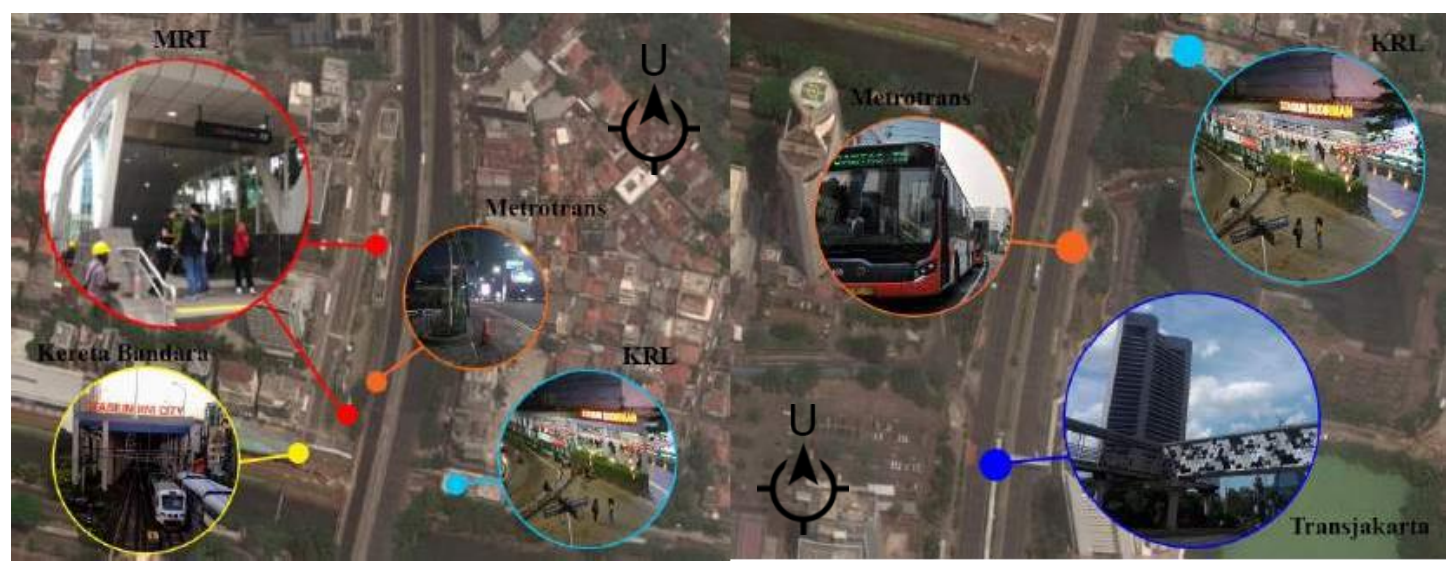

Gambar 5. Moda-moda Transportasi Publik pada TDA 1 dan 2

Sumber: Hasil Observasi dan Olahan Penulis

Konektivitas dari TDA 1 ke TDA 2 relatif jauh menurut jangkauan berjalan kaki di Indonesia, yaitu

$\pm 400 \mathrm{~m}$. Jarak tempuh yang jauh serta harus melewati ruang luar taman menjadikan TDA 1 dan 2 relatif terpisah tidak hanya secara fisik, namun juga secara sistem pergerakan pengguna (dari satu moda transportasi umum menuju moda transportasi umum lainnya). Namun demikian, walaupun konektivitas kedua taman relatif terpisah satu sama lain (lihat Gambar 6), namun bagi pengguna transportasi umum secara umum tetap mudah diakses.

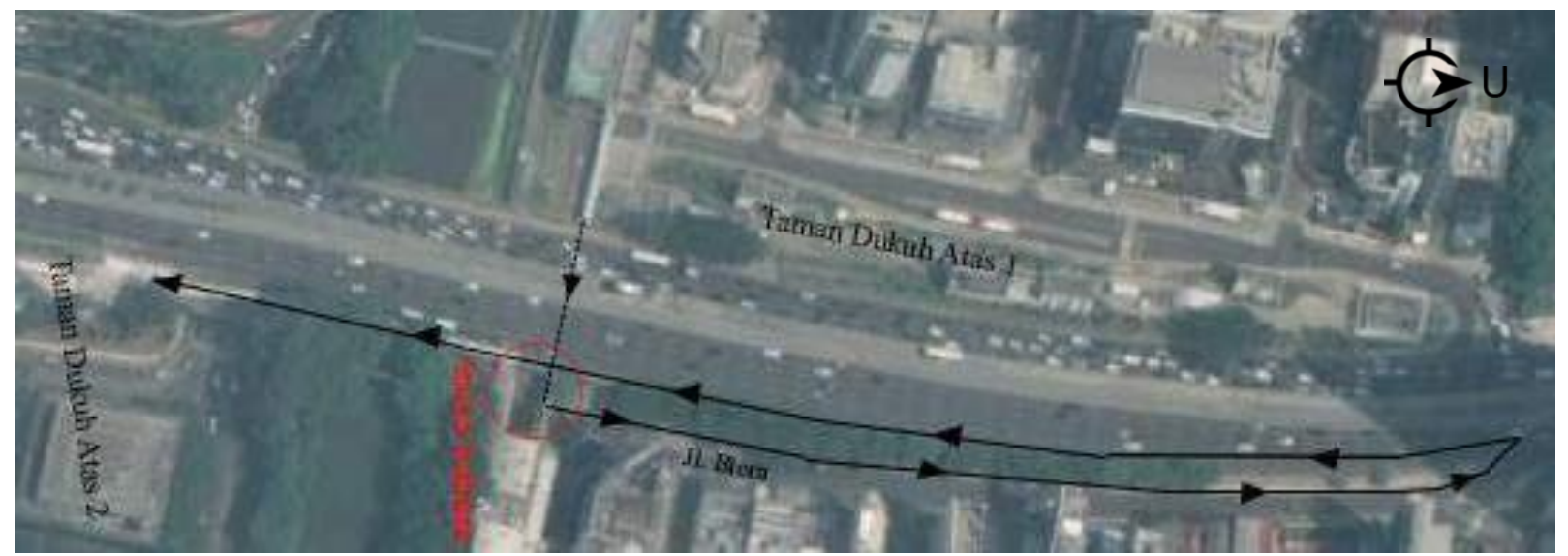

Gambar 6. Rute Berjalan Kaki dari TDA 1 menuju TDA 2

Sumber: Hasil Observasi dan Olahan Penulis

\section{Fasilitas pada Taman Dukuh Atas}

Fasilitas sebagai ruang publik tersedia dengan cukup memadai di TDA. Tabel berikut menunjukkan kelengkapan dimaksud. 
Tabel 1. Fasilitas-fasilitas yang Tersedia di Taman Dukuh Atas Sumber: Olahan Penulis

\begin{tabular}{ccccc} 
Fasilitas & Luasan & Pengguna & Zona Fungsi & Proporsi* \\
\hline Gardu PLN & $244 \mathrm{~m} 2$ & MRT Jakarta & Privat & $0.02 \%$ \\
\hline Parkir Sepeda & $236 \mathrm{~m} 2$ & Pesepeda & Publik & $0.02 \%$ \\
\hline Ventilation Unit MRT & $150 \mathrm{~m} 2$ & MRT Jakarta & Privat & $0.0125 \%$ \\
\hline Lift Difabel & $120 \mathrm{~m} 2$ & Pengunjung MRT & Publik & $0.01 \%$ \\
\hline $\begin{array}{c}\text { Pompa PDAM \& Air Mancur } \\
\text { Siap Minum }\end{array}$ & $12 \mathrm{~m} 2$ & Pengunjung Taman & Publik & $0.001 \%$ \\
\hline Ruang Baca Jakarta & $35 \mathrm{~m} 2$ & Pengunjung Taman & Publik & $0.002 \%$ \\
\hline Terowongan Kendal & $435 \mathrm{~m} 2$ & Pengunjung Taman & Publik & $0.036 \%$ \\
\hline Area Skate Park & $458 \mathrm{~m} 2$ & $\begin{array}{c}\text { Pengunjung } \\
\text { (Komunitas/Individu }\end{array}$ & Publik & $0.038 \%$ \\
$\begin{array}{c}\text { Skateboard \& Sepeda) } \\
\text { Area Viewing Deck }\end{array}$ & $130 \mathrm{~m} 2$ & Pengunjung Taman & & \\
\hline $\begin{array}{c}\text { Perkerasan (trotoar + tempat } \\
\text { duduk) }\end{array}$ & $6043 \mathrm{~m} 2$ & - & Publik & $0.01 \%$ \\
\hline Penghijauan & $4137 \mathrm{~m} 2$ & - & Publik & $50.36 \%$ \\
\hline
\end{tabular}

Keterangan: *terhadap luas total taman, yaitu $12.000 \mathrm{~m} 2$

Meskipun demikian, ada beberapa unsur fasilitas, seperti gardu PLN dan ventilation unit MRT, yang mengganggu kenyamanan pengguna baik dari segi kenyamanan suhu maupun suara. Sehingga, meskipun fasilitas tersebut mendukung tujuan menjadikan TDA sebagai transit hub namun kurang tepat berada di ruang publik.

\section{Apresiasi Pengguna terhadap Taman Dukuh Atas}

Berdasarkan observasi, pengunjung TDA terdiri atas 2 kategori, yaitu: Orang yang melewati TDA (bypasser); dan Orang yang sengaja datang ke TDA untuk memakai fasilitas yang disediakan (visitor).

Dari beberapa informan yang diwawancarai (dirangkum dalam Tabel 2), ada beberapa kecenderungan dalam penggunaan TDA, yakni:

a. Untuk orang yang melewati TDA (bypasser), baik yang akan melakukan transit maupun untuk sekedar beristirahat, waktu yang dibutuhkan untuk cooling down sekitar 15-60 menit.

b. Konektivitas MRT dan Stasiun Sudirman melewati Terowongan Kendal menjadi salah satu penarik terbesar bagi para pengguna (bypasser) untuk memakai transportasi umum.

c. Mayoritas orang yang menggunakan fasilitas taman (visitor) adalah orang yang tinggal tidak jauh dari TDA, sedangkan bagi orang yang melintas (bypasser) untuk menuju transportasi umum, khususnya KRL, adalah orang yang tinggal di luar Jakarta Pusat.

d. Kendala utama yang dirasakan oleh pengguna adalah kurangnya perawatan untuk fasilitas yang tersedia. 
e. Vegetasi dan fasilitas yang sesuai dengan iklim tropis masih dibutuhkan untuk mendukung kenyamanan pengguna.

f. Umumnya bentuk interaksi sosial yang terjadi adalah antarsesama yang sudah mengenal satu sama lain. Kemungkinan terbesar adalah bagi beberapa komunitas olahraga yang menggunakan fasilitas bersama-sama (skateboard dan sepeda).

Tabel 2. Ringkasan Pengguna TDA dan Kendala yang Dihadapinya

Sumber: Wawancara langsung

\begin{tabular}{|c|c|c|c|c|c|}
\hline Informan & $\begin{array}{l}\text { Durasi per } \\
\text { kunjungan }\end{array}$ & $\begin{array}{c}\text { Durasi per } \\
\text { minggu }\end{array}$ & Tujuan & $\begin{array}{c}\text { Moda } \\
\text { Transportasi }\end{array}$ & Kendala \\
\hline Agnestasia (29) & 4 jam & $1-2$ kali & Yoga & Bis kota & $\begin{array}{c}\text { Kurang } \\
\text { vegetasi }\end{array}$ \\
\hline Iqbal Hadi (30) & 3-4 jam & 3-4 kali & Atraksi Sepeda & Sepeda & $\begin{array}{l}\text { Perawatan } \\
\text { fasilitas }\end{array}$ \\
\hline Sultan (17) & 3-4 jam & 3 kali & Skateboard & Ojek daring & - \\
\hline Markus (28) & 30 menit & 1-3 kali & $\begin{array}{c}\text { Istirahat } \\
\text { sebelum } \\
\text { menaiki KRL }\end{array}$ & KRL & Spot berteduh \\
\hline Andrianza (23) & $30-60$ menit & $\begin{array}{l}\text { Setiap pulang } \\
\text { bekerja }\end{array}$ & $\begin{array}{c}\text { Istirahat, } \\
\text { mengobrol dengan } \\
\text { teman kerja }\end{array}$ & KRL & $\begin{array}{c}\text { Perawatan } \\
\text { fasilitas }\end{array}$ \\
\hline Aji (28) & $15-60$ menit & $\begin{array}{c}\text { Setiap pulang } \\
\text { bekerja }\end{array}$ & $\begin{array}{c}\text { Makan sore, } \\
\text { istirahat }\end{array}$ & MRT lalu KRL & - \\
\hline Kiki Surya (30) & $15-60$ menit & 1-2 kali & Makan sore & MRT & 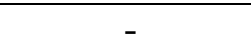 \\
\hline
\end{tabular}

Menurut pengakuan Zara (wawancara, 21 Oktober 2020), salah satu penampil yang sudah melakukan pentas beberapa kali di Musik Tepi Barat, antusiasme dan apresiasi masyarakat terhadap pentas musik cukup tinggi. Banyak bypasser TDA yang memutuskan untuk berhenti, duduk, dan menikmati musik. Interaksi antara masyarakat penikmat musik dan penampil juga terjalin baik, dengan adanya permintaan untuk memainkan lagu tertentu. Interaksi dengan masyarakat penikmat menjadikan kegiatan yang dilakukan tidak hanya menjadi satu etalase, namun juga memberikan pengalaman ruang yang baru.

Namun, terdapat pula fasilitas yang mungkin kurang layak-pakai. Saat rush hour di sore hari, sering terlihat anggota masyarakat yang bermain skateboard di bagian trotoar yang seharusnya disediakan untuk pejalan kaki (lihat Gambar 7). Ini mengindikasikan fasilitas skateboard mungkin kurang terawat sehingga menjadi kurang layak pakai. Seorang nara sumber, Hadi (30 tahun) mengatakan “....karena (situasinya) crowded, dan ada teman-teman skateboard juga (yang mengatakan demikian). Kalau saya pribadi sih maklum...karena apa...ini kan fasilitas umum, dan tidak banyak juga di Jakarta..." (wawancara, 16 Mei 2020). 


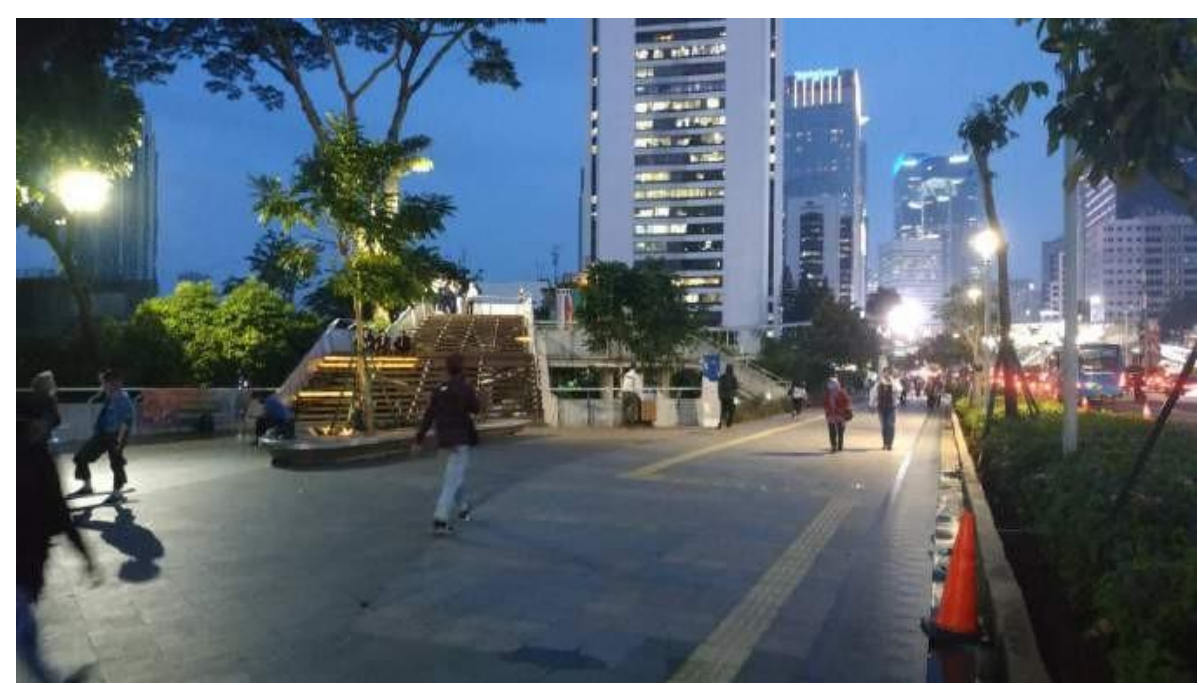

Gambar 7. Suasana Taman pada Sore Hari

Sumber: Dokumentasi Penulis

Waktu berkunjung yang banyak diminati adalah sore hari. Data Google (2020) menunjukkan pergerakan pengunjung tersebut (lihat Gambar 8 dan Gambar 9), baik pada hari kerja maupun akhir pekan. Sore hari merupakan waktu sebagian pengguna pulang kerja; pada akhir pekanpun, pengguna cenderung merasa kurang nyaman berkunjung pada siang hari.

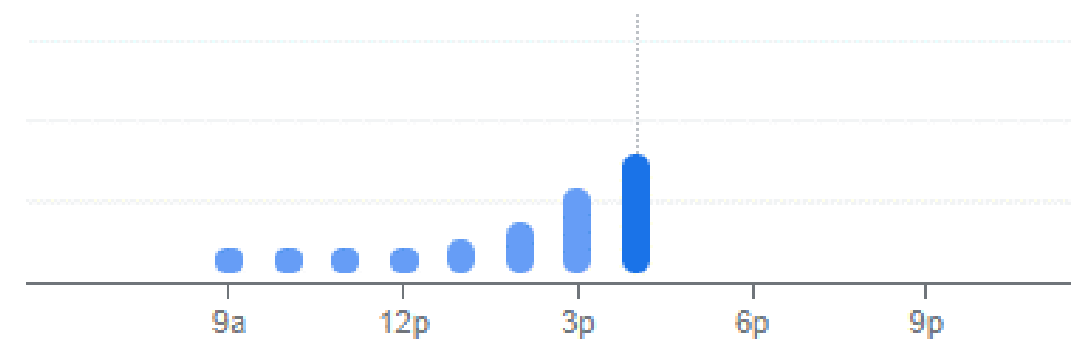

Gambar 8. Jam Kunjungan pada Hari Kerja (Senin-Jumat)

Sumber: Google (2020)

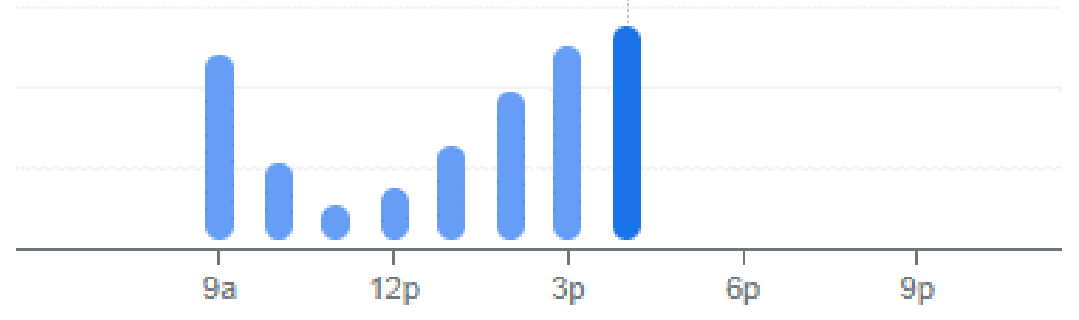

Gambar 9. Jam Kunjungan pada Akhir Pekan (Sabtu dan Minggu) Sumber: Google (2020) 
Ada 2 faktor yang diperkirakan berperan di sini. Pertama, karena faktor cuaca yang panas. Kedua, menurut Nirwono Joga (wawancara 25 Agustus 2020), seorang ahli lansekap, karena masih minimnya budaya bertaman di Indonesia. Di negara yang budaya bertamannya relatif tinggi, seperti Jepang dan Korea, masyarakat rutin mengunjungi taman di siang hari ketika sedang istirahat bekerja. Budaya untuk makan siang di taman sudah menjadi kebiasaan di negara-negara tersebut, sehingga apresiasi terhadap taman menjadi tinggi. Keinginan untuk merawat fasilitas pun menjadi tinggi karena taman sudah menjadi bagian dari aktivitas mereka sehari-hari.

\section{Tinjauan Taman Dukuh atas sebagai ruang publik kota dan ruang ketiga}

Apresiasi pengguna terhadap pencapaian TDA sebagai ruang publik, ataupun pemberitaan media massa tentang TDA, belum terlalu banyak. Hal ini diduga terjadi karena taman itu sendiri belum cukup lama berdiri, dan juga pandemi sejak awal tahun 2020 mengakibatkan banyak ruang publik ditutup demi mencegah penyebaran Covid-19.

Apresiasi TDA sebagai ruang ketiga sebagaimana dicanangkan saat peresmiannya, tampaknya cukup baik. Pemanfaatan TDA sebagai tempat pementasan musik bagi komunitas seniman, berolahraga bagi komunitas olah raga tertentu (yoga, sepeda) telah menunjukkan eksistensi TDA sebagai ruang sosial, tempat warga kota bersosialisasi dengan warga lainnya. Walaupun kecenderungan berkunjung pada siang hari masih rendah karena faktor cuaca atau lainnya, namun besarnya minat warga kota untuk datang pada sore hari, baik pada hari kerja maupun (atau terutama) pada akhir pekan, menunjukkan kebutuhan yang tinggi akan ruang ketiga tersebut. Taman Dukuh Atas telah menjawab kebutuhan warga akan ruang publik yang terbatas, terlebih yang dapat dinikmati di sela waktu saat pulang kerja, atau akhir pekan.

\section{Persandingan teoritis}

Sebagai refleksi terhadap eksistensi TDA sebagai ruang publik, dapat dilakukan penyandingan dengan kriteria ruang publik yang dipandang berhasil menurut Carr et al. (1992: 19), Landman (2016: 28), dan Whyte (1988: 89-92). Kriteria yang ditinjau adalah:

a. Permeabilitas

Kemudahan akses ditinjau dari dua sisi, yaitu dari gedung-gedung di sekitar TDA menuju TDA, dan dari TDA menuju moda transportasi umum, dan sebaliknya. Akses dari gedung sekitar dapat dikatakan mudah, terbukti dengan banyaknya pengguna yang bekerja di sekitar kantor untuk sekedar beristirahat sebelum melanjutkan perjalanan. Akses moda transportasi juga mudah karena TDA termasuk dalam pengembangan TOD (Transit Oriented Development). Namun demikian, masih terdapat satu kendala, yakni konektivitas antara TDA 1 dan TDA 2 yang masih terpisah.

b. Keamanan

Belum adanya CCTV pada TDA menjadikan patroli fisik satpol PP menjadi suatu keniscayaan. Sejauh ini tidak ada pemberitaan tindak kriminal yang terjadi di TDA, selain keluhan pengguna (bypasser dan visitor) berupa kerusakan pada sejumlah fasilitas seperti area skateboard dan viewing deck sehingga pengawasan perlu dilakukan di samping meningkatkan kesadaran pengguna untuk menjaga fasilitas yang ada.

c. Aktivitas

Aktivitas yang berjalan di TDA tidak hanya aktif namun juga pasif, seperti beristirahat di taman, menikmati pemandangan dan suasana kota, dan juga interaksi antarwarga kota. Semua aktivitas tersebut dilakukan di TDA. 


\section{d. Kemampuan beradaptasi}

Menurut Margono dan Zuraida (2019: 27-31), taman modern harus dapat 'dikonsumsi' pada hari kerja dan akhir pekan. Kegiatan yang dilakukan pada TDA bisa menjadi contoh yang baik, yaitu adanya tingkat pengunjung yang stabil setiap harinya, termasuk di hari libur. Adaptasi kegiatan yang dilakukan pada car-free day menjadikan banyak variasi kegiatan yang terjadi selain istirahat, skateboarding, dan sepeda.

e. Kenyamanan

Tingkat kenyamanan TDA dapat ditinjau dari komunitas skateboard dan sepeda. Sebelumnya, komunitas ini bermain di Skatepark Pasar Rebo. Sekarang (2020), komunitas ini telah menjadikan TDA sebagai altenatif tempat bermain yang layak. Beberapa informan juga menyampaikan terjadinya pergeseran kebiasaan dari beristirahat di lobi kantor menjadi beristirahat di TDA. Hanya saja pada siang hari belum banyak yang menjadikan TDA sebagai opsi tempat beristirahat dikarenakan cuaca yang panas.

Berkaitan dengan pencanangan TDA sebagai ruang ketiga, maka TDA dapat disandingkan dengan karakteristik ruang ketiga menurut Oldenburg (1999: 26). Karakteristik ruang ketiga dimaksud adalah:

a. Bersifat sebagai common ground

Tidak ada kelompok masyarakat, atau pengguna tertentu, yang menguasai taman tersebut. Baik orang yang melewati TDA (bypasser) maupun pengguna fasilitas (visitor) dapat beraktivitas berdampingan tanpa saling mengganggu. Pada pertunjukan musik, penampil juga berinteraksi dengan pengunjung, sehingga menjadikan hubungan penampil dan penonton cair. Hal ini menjadikan kedua kategori pengguna dapat berhenti dan menikmati musik.

b. Aksesibilitas dan akomodasi

Sama seperti kriteria ruang publik, aksesibilitas ke transportasi umum juga penting pada ruang ketiga. Kemudahan akses menjadikan tempat yang notabene jauh dari rumah terjangkau dan aman bagi pengunjung yang baru datang sekalipun.

c. Adanya pengguna tetap

Sama dengan Oldenburg, Sinaga (wawancara, 14 Mei 2020) sebagai peneliti ruang ketiga juga berpendapat bahwa ruang ketiga harus mempunyai pengguna yang stabil baik frekuensi maupun durasi. Menurut beberapa informan, dengan frekuensi kunjungan rata-rata 3-4 kali seminggu, mereka telah menjadikan TDA sebagai tempat persinggahan reguler mereka. Dengan kata lain, TDA telah menjadi bagian dalam rangkaian aktivitas harian atau mingguan mereka.

d. Sederhana

Tidak adanya iklan-iklan dan sponsor menjadikan suasana TDA relatif sederhana dan apa adanya. Tetapi untuk lebih memastikan keberlanjutan pengadaan ruang publik, khususnya di pusat kota, keberadaan iklan atau sponsor dapat dipertimbangkan sebagai salah satu alternatif pendanaan dengan tetap mengatur hak dan kewajiban pengguna dan pengiklan.

e. Menyenangkan

Sejalan dengan kriteria ruang publik, yaitu kenyamanan, suasana yang ada di TDA cukup memberikan pengalaman baru sebagai oase bagi para pekerja kantor yang hendak pulang dengan beristirahat sambil berswafoto dengan latar suasana perkotaan.

Taman Dukuh Atas telah juga memenuhi berbagai tujuan pengadaannya, sebagaimana dipaparkan oleh Dinas Bina Marga DKI Jakarta, yakni: 
a. Meningkatkan persentase RTH di pusat kota, meskipun persentase penghijauan masih relatif sedikit, yakni hanya $34,47 \%$ dari keseluruhan luas TDA.

b. Memberikan pengalaman ruang baru bagi warga Kota Jakarta dalam menjalankan aktivitas harian atau mingguannya.

c. Menghidupkan ruang terbuka publik di pusat Kota Jakarta dari pagi hingga malam hari (setelah jam pulang kerja). Dari observasi terlihat bahwa pada malam hari ketika jam pulang kerja, suasana TDA relatif hidup karena adanya pengguna yang melintas menuju stasiun KRL dan MRT. Banyak juga pengunjung yang datang ketika hari sudah gelap untuk bermain skateboard sehingga suasana menjadi ramai dan terasa aman. Namun, minimnya penggunaan pada siang hari menunjukkan tujuan ini belum terpenuhi sepenuhnya.

d. Meningkatkan interaksi sosial dan budaya, serta menghilangkan gap kelas sosial masyarakat Kota Jakarta. Hasil wawancara dengan penampil musik menunjukkan ketika mereka menyjikan musik di TDA, banyak sekali pengunjung yang awalnya tidak saling kenal satu sama lain memutuskan untuk berhenti sejenak dan mengobrol. Ini menjadi salah satu pertanda mencairnya interaksi sosial dan hilangnya gap sosial di antara mereka. Interaksi yang terjadi antara penonton dan penampil juga menjadi salah satu pertanda bahwa penampil musik tidak merasa menjadi ornamen dalam taman tetapi merupakan bagian dari pengunjung taman.

e. Menambah rasa aman warga kota untuk berjalan/beraktivitas di ruang publik karena merasa terawasi. Selaras dengan butir 3 di atas, adanya aktivitas yang berlangsung hingga malam hari menjadikan warga yang melintas di sekitar TDA merasa aman dan terawasi.

f. Sebagai katalis dalam mendorong terciptanya kota layak huni dan ramah terhadap pejalan kaki. Indikator keberhasilan ini masih terbatas karena adanya pandemi pada saat penelitian diadakan (2020), sehingga jumlah pejalan kaki dan frejuensi transportasi umum juga berkurang. Namun ada informan yang mengaku berpindah ke transportasi umum karena akses dari tempat bekerja ke moda transportasi umum relatif lebih mudah dan aman.

\section{KESIMPULAN DAN SARAN}

\section{Karakter Taman Dukuh Atas}

Sebagai ruang publik, TDA secara garis besar sudah memenuhi kriteria ruang publik yang dipandang berhasil. Sebagai program Pemda, TDA juga sudah memenuhi sejumlah karakteristik dari ruang ketiga, seperti adanya pengguna reguler (durasi dan frekuensi) yang memilih untuk beristirahat dan mengobrol di TDA dibandingkan dengan di lobby kantor mereka.

Kendala dalam mengadakan ruang publik aktif5 yang bertujuan untuk menarik minat masyarakat beraktivitas di TDA adalah dikorbankannya area penghijauan pada taman tersebut. Ini yang menjadi alasan kurang berhasilnya Pemda DKI dalam tujuannya untuk meningkatkan persentase RTH di Jakarta melalui TDA. Area hijau sebesar $34.47 \%$ dari luas keseluruhan TDA masih jauh di bawah standar persentase hijau di pusat kota ditinjau dari Permen PU no.5 Tahun 2008 tentang Pedoman Penyediaan dan Pemanfaatan Ruang Terbuka Hijau di Kawasan Perkotaan dengan area hijau pada taman minimal $80 \%$ dari luasan. Sehingga TDA lebih dikategorikan sebagai ruang publik dibandingkan sebagai ruang terbuka hijau publik. Peningkatan secara desain dapat menjadi salah satu solusi untuk mengatasi kendala tersebut. Berikut beberapa alternatif solusi desain pada TDA, yakni:

a. Beberapa titik yang dapat menjadi kanopi akan mempermudah untuk penampil dan pengunjung untuk berteduh dari terik matahari dan hujan.

b. Memperbanyak penanaman melalui enrichment planting menggunakan jenis-jenis tanaman yang mempunyai kemampuan tinggi untuk menyerap CO2, sehingga suhu udara khususnya di trotoar dan area istirahat dapat turun.

c. Titik berteduh tersebut dapat berupa pot tanaman yang bersifat portable sehingga dapat fleksibel sesuai dengan kegiatan yang berlangsung. 


\section{Sistem Pengelolaan Taman Dukuh Atas}

TDA direncanakan dibangun pada tahun 2018 dan selesai pada Agustus 2019. Pembangunan dilaksanakan oleh Dinas Bina Marga DKI Jakarta, dan didanai oleh Keppel Land Indonesia sebagai kompensasi pelampauan KLB, sesuai Pergub DKI No 210/2016 tentang Pengenaan Kompensasi terhadap Pelampauan Nilai Koefisien Lantai Bangunan. Pihak lain yang terlibat adalah Dinas Pertamanan (konsultasi mengenai perawatan tanaman di TDA), Dinas Perhubungan (mengatur lalu lintas yang direkayasa setelah adanya TDA), dan Dinas Pariwisata (mengatur event dan kegiatan yang berlangsung melalui Musik Tepi Barat) dalam mengelola TDA.

Untuk mendapat gambaran tentang hal-hal yang perlu dibenahi setelah TDA terbangun, menarik menyandingkan TDA dengan taman lain, misalnya RPTRA Kalijodo. Tempat ini dipilih karena ada beberapa kemiripan dengan TDA, misalnya dari segi luasan, pembiayaan (RPTRA Kalijodo dibiayai melalui CSR [Corporate Social Responsibility] perusahaan, sementara TDA melalui kompensasi pelampauan KLB), serta pengelolaan yang berbeda dari RPTRA lain, yaitu berada langsung di bawah beberapa dinas terkait seperti Dinas Kehutanan, Dinas Perhubungan, serta Dinas Pemberdayaan Perlindungan Anak dan Pengendalian Penduduk (Ramadhan, 2018).

Menurut Wakil Gubernur DKI Jakarta (dalam Ramadhan, 2018), salah satu kekurangan RPTRA Kalijodo adalah tidak terawatnya taman karena birokrasi yang berbelit-belit. RPTRA Kalijodo adalah RPTRA terluas namun perawatannya dilaksanakan oleh beberapa satuan kerja perangkat daerah (SKPD), sehingga menjadikan koordinasi sulit dilakukan. Hal ini juga menjadi salah satu kendala pada TDA, yaitu sulitnya birokrasi untuk sekedar meminta izin maupun mengetahui data antar-dinas karena berbagai dinas hanya mengurus cakupan kerjanya masing- masing.

\section{Pengembangan Ruang Publik Modern}

Sistem pengelolaan TDA sebagai ruang publik modern perlu mengadopsi mekanisme kerja yang berbeda, misalnya dalam pengadaan acara. Pada saat ini, TDA dikelola oleh Dinas Bina Marga bekerjasama dengan Dinas Pertamanan, Dinas Perhubungan, dan Dinas Pariwisata. Untuk menghindari masalah yang sama (yakni sulitnya proses perizinan acara), perlu dibentuk unit kerja pengelola ruang publik di Jakarta yang menjadi perwakilan dari dinas-dinas terkait. Kriteria yang perlu dicapai agar pengelola ruang publik tersebut dapat berkelanjutan, yakni

a. Fleksibel

Tidak birokratis, memiliki jam kerja yang dapat disesuaikan dengan aktivitas di TDA, menerapkan prosedur kerja (SOP - standard operating procedur, berkaitan misalnya dengan permohonan kerjasama, dan permohonan penggunaaan taman) yang memudahkan pemohon, atau dapat disesuaikan dengan kebutuhan spesifik pemohon. Penerapan sistem keamanan yang fleksibel selama tetap dalam koridor aktivitas-aktivitas yang legal namun dalam bentuk pengawasan tidak langsung (menggunakan kamera CCTV) sehingga pengguna tidak merasa tertekan namun tetap mendapatkan rasa aman.

b. Informatif

Segala informasi terkait penyediaan fasilitas dan aturan yang berlaku harus mudah dimengerti dan dijangkau oleh masyarakat termasuk dengan menggunakan media sosial (facebook, twitter, instagram, whatsapp) untuk penyampaian informasi, kritik, dan saran.

c. Dapat beradaptasi

Cepat menyesuaikan diri dengan tuntutan pengguna (yang berubah), berdasarkan kritik dan saran yang diberikan dan survei yang dilakukan secara berkala oleh pengelola.

\footnotetext{
${ }^{5}$ Taman yang memiliki fungsi sebagai tempat bermain dan olahraga, dilengkapi dengan elemen-elemen pendukung taman bermain dan lapangan olahraga.
} 
d. Sumber dana yang berkelanjutan

Untuk memenuhi tuntutan di atas, harus ada mekanisme pengumpulan dana, misalnya dari pemasangan iklan di beberapa titik serta retribusi dari penyewaan tempat untuk acara besar, outlet komersil, dan lain-lain.

Pengelolaan yang baik adalah salah satu penentu keberlanjutan ruang publik. Unit kerja yang fokus mengelola ruang publik diharapkan dapat menambahkan (mengadakan), mengoperasikan, dan merawat ruang publik tersebut dengan bantuan terbatas Pemda DKI Jakarta.

\section{REFERENSI}

Carr, S., Francis, M., Rivlin, L., \& Stone, A. (1992). Public space. NY: Cambridge University Press. Creswell, J. W. (1994). Research design: Qualitative \& quantitative approaches. Thousand Oaks,CA: Sage Publications.

Haryanto, I. (2019). Anies Baswedan resmikan taman spot budaya 2 di Dukuh Atas. Diakses pada 27 Januari 2020 https://news.detik.com/berita/d-4670525/anies-baswedan-resmikan-tamanspot- budaya-2-di-dukuh-atas

Ibrahim, L.D. (1998). Masyarakat perkotaan dan perubahan kondisi lingkungan. Dalam A. Suryana, Globalisasi, suburbanisasi Jakarta dan transformasi sosial ekonomi Depok. Yogyakarta: Universitas Gadjah Mada. pp 1-20.

Landman, K. (2016). Shopping malls with quasi-public spaces in Pretoria: Neo-traditional consumption space or controlled village commons?. University of the Free State: Town and Regional Planning, 69(3), pp 26-38. https://www.doi.org/10.18820/2415-0495/trp69i1.3

Lefebvre, H. (1991). The production of space. Oxford: Basil Blackwell.

Margono, R. B., \& Zuraida, S. (2019). Public space as an urban acupuncture: Learning from Bandung, Indonesia. Journal of Applied Science, 1(1), pp 22-33. https://doi.org/10.36870/japps.v1i1.5

Oldenburg, R. (1991). The great good place. NY: Marlowe \& Company.

(1999). The great good place: Cafes, coffee shops, bookstores, bars, hair salons, and other hangouts at the heart of a community (3rd ed.). NY: Marlowe \& Company.

Priatmodjo, D. (2012, 20-24 Mei). Public space in scarce urban land: Case of Jakarta. Dalam 49th International Making Cities Livable Conference on True Urbanism: Planning Healthy Communities For All, Portland, pp 1-12.

Ramadhan, A. (2018). Kalijodo kini dan pembangunan yang disebut tidak "sustainable". Diakses pada November 2020 https://megapolitan.kompas.com/read/2018/07/24/06571281/kalijodo- kini-danpembangunan-yang-disebut-tidak-sustainable ?page $=$ all

Soja, E. W. (1996). Thirdspace: Journeys to Los Angeles and other real-and-imagined places. Oxford: Basil Blackwell.

Stakes, R. E. (1994). Case studies. Dalam N. K. Denzin \& Y. S. Lincoln, Handbook of qualitative research. Thousand Oaks, CA: Sage Publications, pp 236-247.

Terzi, C. dan S. Tonnelat. (2016). The Publicization of Public Space. Environment and Planning A, 49(3), pp 519-536. https://doi.org/10.1177/0308518X16665359

Whyte, W. H. (1988). Rediscovering the center. Dalam J. Moore, Riccarton - The Art of a Third Place in a First Suburb. New Zealand: Lincoln University, pp. 79-96. 